\title{
THE WAY WE WERE
}

\section{The architect of sustained yield forestry}

By John Parminter, RPF

Forest History Association of $B C$

Most discussions about the history of forest policy in British Columbia involve mention of C.D. (Dick) Orchard, the province's fifth chief forester. Orchard was born at Lower Wakefield, New Brunswick, a locale he described as just "a wide spot in the road." He was a school principal for years before switching careers. He went on to receive a forestry degree from the University of New Brunswick in 1920. After working briefly for the New Brunswick Forest Service, he moved to BC because "distant fields looked greener." He started working for the BC Forest Branch, intending to stay only two years.

Orchard began with the management office in Victoria and was soon involved with forest inventories in the Nass and Okanagan regions. By 1923 he was supervising all forest survey work and organizing summer field crews. During the 1920s and 1930s, Orchard held various senior positions in the Forest Branch and became chief forester in 1941 following E.C. Manning's death. In 1945 he assumed the dual role of chief forester and deputy minister of forests, holding both until his retirement in 1958.

Two significant events took place during Orchard's term as chief forester - the second and third provincial royal commissions on forestry (1944-1945 and 1955-1956 respectively). Both were headed by the Hon. Gordon McGregor Sloan. Dick Orchard figures prominently in both commissions, the outcome of the first being sustained yield forest management legislation and the creation of several new forms of forest tenure, notably what is now the tree farm license. Sloan said of Orchard:

"He may be truly regarded as the chief architect of our present policy of sustained-yield forest management. It was his insistence that such a policy be inaugurated that led to the 1944-45 commission, and it was largely upon his shoulders that the onerous responsibility rested of translating the broad outlines of my 1945 recommendations into detailed legislation acceptable to the government."

In recognition of Orchard's contributions to forestry, his alma mater granted him an honorary doctoral degree in 1947 . He was a charter member of the Association of BC Professional Foresters, president of the second ABCPF council in 1949 and the first recipient of the CIF's Canadian forestry achievement award and gold medal in 1967.

Early in his retirement from the Forest Service, Dr. Orchard taught forest policy at the University of British Columbia and collected a wealth of information on the province's forest history, now housed at UBC and the provincial archives. His original intention to stay out west for just two years was altered somewhat, as his tenure with the Forest Service lasted for 38 years. As a result, his influence on forest management in this province was quite considerable.

Formed in 1982, the Forest History Association of BC covers a wide spectrum of interests - from the history of men and machines to the evolution of forest resource management and the associated social and political aspects. Their newsletter is published four times per year and an annual meeting and field trip are held each June. For membership information contact Mr. E. Nyland, 8793 Forest Park Drive, Sidney, BC, V8L 4E8.

Source: "Forum:, ABCPF Magazine

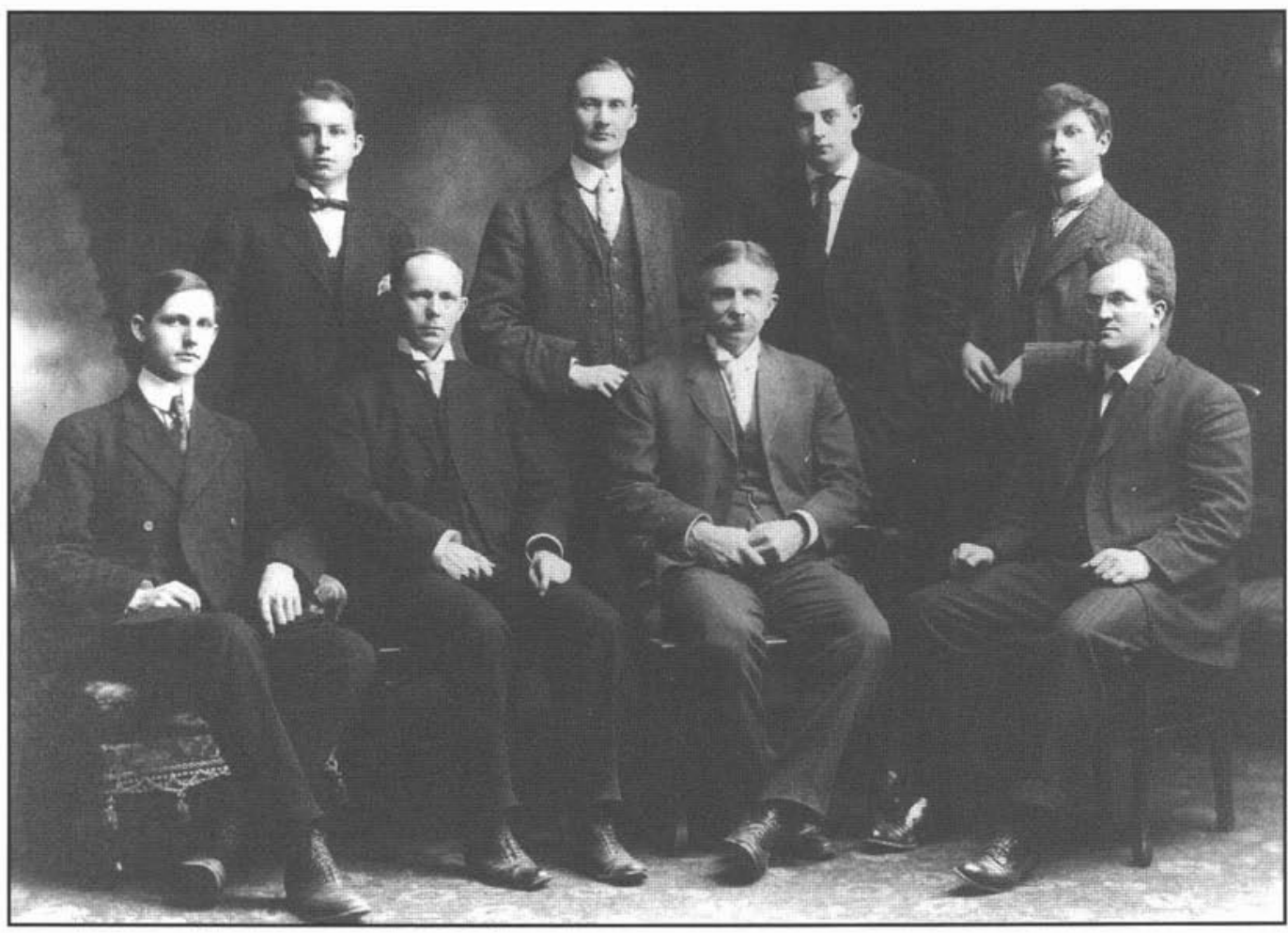

Faculty and Students, University of Toronto, 1906-1908.

Standing,

$L$ to $R$, L.M. Ellis, JH. White, M.A., F.M. Mitchell, R.P. Wodehouse. Seated, T.W. Dwight, A.H.D. Ross, M.A., M.F., B.E. Fernow, LL., E.J. Zavitz, BA, M.S.F. 